\title{
Utilization of Public Key Infrastructure to Facilitates the Role of Certification Authority in Cyber Notary Context in Indonesia
}

\author{
Swante Adi Krisna*; Hari Purwadi \\ Faculty of Law, Universitas Sebelas Maret, Indonesia \\ Email: swantexadixkrisna@myself.com
}

http://dx.doi.org/10.18415/ijmmu.v5i2.392

\begin{abstract}
Notary's concept as Registration Authority has been facilitated by Indonesian law, for example Law Number 2 Year 2014 About Amendment to Law Number 30 Year 2004 Concerning Notary Public, which explains that "other authorities regulated in legislation", the authority to certify electronic transactions (Cyber notary), make a Deed of pledge of waqf, and mortgage of aircraft. In addition to Law Number 2 Year 2014 on Amendment to Law Number 30 of 2004 concerning Notary Public, Notary's role as Registration Authority is also described in Government Regulation Number 82 Year 2012 Concerning the Implementation of Electronic Transaction System and Transaction, especially in the explanation Article 59 Paragraph (5) explaining that the Ministerial Regulation contains, among other things, arrangements on the procedure of applying for electronic certification which can be submitted through a notary. In contrast to the notary role concept as the Registration Authority, the notary role concept as a subordinate certification authority is not possible because of various obstacles.
\end{abstract}

Keywords: Public Key Infrastructure; Certificate Authority; Cyber Notary

\section{Introduction}

Since the Industrial Revolution, the history of mankind has been accelerated in terms of its multiple strengths, abilities, speed, and efficiency than ever before ${ }^{1}$. The first industrial revolution that occurred in England in 1774 led to a shift in the use of manpower and animals which were replaced by the mechanical technology. Then, the second industrial revolution occurring in the United States is characterized by the use of electric power. Furthermore, the third industrial revolution took place in 1969 in the United States marked by the use of power tools and Information Technology, until now it has reached the fourth Industrial Revolution. As for the difference between the third industrial revolution and the fourth industrial revolution is where the third industrial revolution the tools used are still working independently whereas in the fourth industrial revolution all the tools are connected through the internet system otherwise known as Cyber ${ }^{2}$.

\footnotetext{
${ }^{1}$ Satjipto Rahardjo. (2009). Hukum dan Perilaku: Hidup baik Adalah dasar Hukum Yang baik, Jakarta: Kompas, page 9.
}

${ }^{2}$ Assafa Endeshaw. (2007). Hukum E-Commerce dan Internet dengan Fokus Di Asia Pasifik, Yogyakarta: Pustaka Pelajar. 
Kenichi Ohmae argues that there are four major problems in the era of globalization: investment, industry, information technology and individual consumer which ultimately causes the boundaries of political maps and borders between countries to disappear, thus creating a new cross-country economic field gave birth to new forms of nearby communities, such as $\mathrm{ASEAN}^{3}$. Further Information technology has also triggered and spurred changes in the social life and social needs of the community, which previously conventional transactions to electronic transactions, is considered more effective and efficient ${ }^{4}$.

Aron Mefford argues that the use of information technology makes the existence of a paradigm shift in society in determining the identity of a legal act, ie from citizen to netizen ${ }^{5}$. The paradigm shift in the community can be seen in research conducted by Google in 2015. Google launches a study that one in three searches through Google is related to e-commerce and $66 \%$ of those searches are done via mobile. Furthermore, along with the rapid development of machine learning and artificial intelligence, today the world is experiencing a shift from the use of conventional e-commerce to the use of chatbots to provide information and answer every user's questions quickly and efficiently, conducted by eBay to close the gap between e-commerce and conventional trading.

The development of e-commerce can be the beginning of the application of a cyber notary mechanism in Indonesia ${ }^{6}$. In addition to maintaining the security of state secrets, the Government of Indonesia actually has a Public Key Infrastructure known as SiVion which has passed ISO 27001/ ISMS certification with international standards to support the application of cyber notary.

Public Key Infrastructure is a formal structure used to transfer information, funds and other sensitive materials electronically by using a pair of encrypted keys provided by and distributed through a trusted entity, the Certificate Authority (CA) and the Registration Authority (RA). The Certi fi cate Authority is an authorized entity to publish and verify an encrypted electronic certificate, while the Registration Authority is an entity that has the primary role and responsibility to validate the subject's identity in the framework of approval for the application of the certificate sent to the Electronic Certification Operator. With the development of National Public Key Infrastructure, it is expected to trigger the development of Cyber Notary in Indonesia and realize the independence of the nation in the field of Information Technology. Cyber notary here is not only judged based on the use of computerization and the internet in the administration of notary office but also more marked by the increasing function and role of the notary in an electronic transaction or even organizing its services electronically ${ }^{7}$.

With the benefit of transferring the conventional deed into the above electronic deed, it is necessary to enable Electronic Certification Authority (or also known as Certificate Authority) in electronic proofing ${ }^{8}$. Electronic Certification Organizer under the ITE Law is a legal entity that serves as a trustworthy party, who provides and audits the Electronic Certificate. Electronic Certification Organizer in Government Regulation Number 82 the Year 2012 on Electronic System and Transaction Implementation Article 60, has the authority to conduct inspection of prospective owners and/or holders of Electronic Certificates; issuance of Electronic Certificate; renewal of Electronic Certificate; blocking and revocation of Electronic Certificate; Electronic Certificate validation; and making a list of active and frozen Electronic Certificates. It is this Electronic Certification Operator who will become a "notary"

\footnotetext{
${ }^{3}$ Achmad Ali. (2011). Menguak Tabir Hukum, Ghalia Indonesia, Bogor, page 167.

${ }^{4}$ Mahmutarom. (2006). Pembangunan Hukum Nasional dalam Konteks Global, dalam Menggagas Hukum Progresif Indonesia, Yogyakarta: Pustaka Pelajar, page 178.

${ }^{5}$ Arsyad Sanusi. (2005). Hukum Dan Teknologi Informasi, Jakarta: M. Arsyad Sanusi, hal 31.

${ }^{6}$ Sukarmi. (2008). Cyber Law: Kontrak Elektronik dalam Bayang-Bayang Pelaku Usaha (Cyberlaw Indonesia), Pustaka Sutra, Bandung, hal 138.

${ }^{7}$ Satjipto Rahardjo, Merencanakan Pembangunan Hukum Dalam Era Demokrasi, Transparasi dan Perkembangan Sains, Seminar dan Temu Hukum Nasional IX di Yogyakarta 20-21 November 2008.

${ }^{8}$ Edmond Makarim. (2013). Notaris dan Transaksi Elektronik: Kajian Hukum Tentang Cybernotary atau Electronic Notary, Depok: Rajagrafindo Persada, page 12.
} 
verifying the identity of a person in the application of cyber notary, followed by providing a certificate that guarantees the public key of a particular individual. The Organizer of the Electronic Certification Authority may, at last, be a witness concerning the proof of the electronic transaction under its control.

Notary's concept as Registration Authority has been facilitated by legislation in Indonesia, for example: Law Number 2 Year 2014 About Amendment to Law Number 30 Year 2004 Concerning Notary Public Offering, especially in Dispelling Article 15 Paragraph (3), which explains that "other authorities regulated in legislation", inter alia, the authority to certify electronic transactions (Cyber notary), make a Deed of pledge of waqf, and mortgage of aircraft. In addition to Law Number 2 Year 2014 on Amendment to Law Number 30 of 2004 concerning Notary Public Notary's role as Registration Authority is also described in Government Regulation Number 82 Year 2012 Concerning the Implementation of Electronic Transaction System and Transaction, especially in the explanation Article 59 Paragraph (5) explaining that the Ministerial Regulation contains, among other things, arrangements on the procedure of applying for electronic certification which can be submitted through a notary. In contrast to the notary role concept as the Registration Authority, the notary role concept as a subordinate certification authority is not possible because of various obstacles.

Based on the description above, the authors are interested to discuss how the utilization of Public Key Infrastructure to facilitate the role of Electronic Certificate Organizer in the context of cyber notary viewed from the perspective of progressive legal theory. In this legal research, the author takes the title "UTILIZATION OF PUBLIC KEY INFRASTRUCTURE TO FACILITATES THE ROLE OF CERTIFICATION AUTHORITY IN CYBER NOTARY CONTEXT IN INDONESIA".

\section{Problem Formulation}

Based on the above description of the background, then the research problem can be formulated as follows: How are the changes in legislation related to Information Technology to facilitate the role of Electronic Certificate Organizer in organizing Cyber Notary?

\section{Methodology}

Type of research used is normative legal research. Research approach is statute approach, which is the approach using legislation and regulation and conceptual approach. Statute apprach is used organizational image lexspecialsi derogate legi generali principle. The nature of this research is descriptive to provide detail, systematic and holistic description and data on varied aspects related with the research.

\section{Discussion}

In facilitating the role of Notary as the Registration Authority of an existing Certification Authority, such as in an online fiduciary where Notary is only a party requesting a certificate to the Directorate General of Legal Administration of the Ministry of Justice and Human Rights People online. However, with the facilitated role of Notary as the Registration Authority, the author is of the opinion that a special arrangement is needed to clarify the Notary's role as the Registration Authority itself. Unlike the Notary's role as a Registration Authority, the Notary's role as a Sub-Certification Authority (SubCertification Authority) requires more requirements to be fulfilled by Notary because in addition to acting as a Certification Authority, a Notary is also required to can be an Electronic System Operator. With the role of Electronic Certification Authority then required some necessary changes, namely: 


\section{Registration of Electronic System Provider for Public Service for Individuals}

Article 3 of Government Regulation Number 82 Year 2012 Concerning the Implementation of Electronic Transaction and System provides that: Electronic System Implementation shall be carried out by the Operator of Electronic System. The operation of Electronic Systems as referred to in paragraph (1) may be carried out for: public services; and non-public services.

Whereas in the consideration of the Law of Notary's Office explains that a notary is a certain position that runs a profession in legal services to the public, need to get protection and guarantee for the achievement of legal certainty. Therefore, it shall be stipulated concerning Registration of Electronic System Provider for Public Service for individuals.

\section{The Ministerial Regulations Referred to in Article 7 Paragraph (2) Do not Exist}

Article 7 of Government Regulation Number 82 Year 2012 Concerning the Implementation of Electronic Transaction and System provides that: Software used by the Electronic Systems Provider for public services shall registered with ministries conducting governmental affairs in the field of communications and informatics; ensure the safety and reliability of operations as appropriate; and in accordance with the provisions of legislation. (2) Further provisions regarding Software requirements as referred to in paragraph (1) shall be stipulated in a Ministerial Regulation. The ministerial regulation as meant in Article 7 Paragraph (2) does not exist.

\section{A Special Arrangement Is Required Regarding the Role of Notary as A Trusted Third-Party Source Code Keeper}

Article 9 of Government Regulation No. 82/2012 concerning the Implementation of Electronic Transaction and System provides that the Operator of Electronic Systems shall ensure the confidentiality of the Software source code used. The source code may be examined where necessary for the purpose of investigation.

Whereas in Article 66 Paragraph (1) of Notary Law states that:

For the purposes of the judicial process, the investigator, the public prosecutor, or the judge with the approval of the Regional Supervisory Board is authorized: taking photocopies of Deed and/ or letters attached to Minutes of Deed or Notary Protocol in the Notary's depository; and invokes Notary to be present in the examination relating to the deed which it has made or the Notary Protocol which is in the Notary's depository. Therefore, special arrangements concerning the role of Notary as a trusted third-party source code store or escrow source code and check mechanisms are necessary for the purposes of the investigation.

\section{Obligations Related to Electronic Systems Organizer Management}

Article 14 of Government Regulation Number 82 Year 2012 Concerning the Implementation of Electronic Transaction and System provides that:

The Operator of Electronic System shall have a policy of governance, operating procedures, and periodic audit mechanism of Electronic System. Therefore, there is a need for arrangements related to Electronic Systems Organizer Management so that a Notary can guarantee the availability of service level 
agreements; availability of information security agreement on Information Technology services used; and information security and internal communications facilities are held.

\section{Regulation of Supervisory Agency and Sector Supervisor}

Article 15 Paragraph (3) of Government Regulation Number 82 Year 2012 Concerning the Implementation of Electronic Transaction and System provides that further provisions concerning Personal Data Protection guidelines in Electronic Systems shall be stipulated in a Ministerial Regulation. In the Regulation of Minister of Communication and Information Technology Number 20 of 2016 on Protection of Personal Data in Electronic System Article 7 Paragraph (2) stated that:

The Supervisory and Sector Control Institution may determine relevant information and in accordance with its objectives as referred to in paragraph (1).

Whereas in Article 67 of the Notary Law states that: Supervision over a Notary is performed by the Minister. In conducting the supervision as referred to in paragraph (1) the Minister shall establish the Supervisory Board. The Supervisory Board as referred to in paragraph (2) shall be 9 (nine) persons, consisting of: government as much as 3 (three) people; Notary organizations of 3 (three) persons; and experts/ academics as much as 3 (three) people. Therefore, a strict regulation of the Supervisory and Sector Controlling Institutions is required as a determinant of relevant information criteria in relation to data collection.

\section{Provision of Choice in the Electronic System for the Owners of Personal Data on the Confidentiality or Privacy of the Personal Data}

Article 15 Paragraph (3) of Government Regulation Number 82 Year 2012 Concerning the Implementation of Electronic Transaction and System provides that:

Further provisions concerning Personal Data Protection guidelines in Electronic Systems as referred to in paragraph (2) shall be stipulated in a Ministerial Regulation. In the Regulation of Minister of Communication and Information Technology Number 20 of 2016 on Protection of Personal Data in Electronic System Article 8 Paragraph (2). Respect for the Owner of Personal Data on Personal Data of a privacy nature shall be made through the provision of choice in the Electronic System for the Owner of Personal Data on the confidentiality or privacy of the Personal Data.

Article 16 Paragraph (1) Sub-Article e of the Notary's Office Law explains that: In performing his/ her position, Notary has the obligation to conceal everything concerning the deed which he made and all the information obtained for the deed in accordance with the oath/ promise of office, unless the law specifies otherwise. Therefore, it is necessary to harmonize the legislation.

\section{Provision of Choice in the Electronic System for Personal Data Owners Against Changes, Additions, or Updates of Personal Data}

Article 15 Paragraph (3) of Government Regulation Number 82 Year 2012 Concerning the Implementation of Electronic Transaction and System provides that: Further provisions concerning Personal Data Protection guidelines in Electronic Systems as referred to in paragraph (2) shall be stipulated in a Ministerial Regulation. In the Regulation of Minister of Communication and Information Technology Number 20 of 2016 on Protection of Personal Data in Electronic System Article 8 Paragraph 
(2) letter b mentioned that: Respect for the Owner of Personal Data on Personal Data of a privacy nature as referred to in paragraph (1) shall be made through the provision of choice in the Electronic System for the Owners of Personal Data against changes, additions, or updates of Personal Data.

Whereas in Article 48 of the Law of the Notary Office explains that: The contents of the deed may not be altered or supplemented, either in the form of writing of overlap, insertion, deletion or deletion and replacing it with another. Changes to the deed in the form of additions, replacements or deletions in the deed are only valid if such change is initialed or otherwise marked by the witnesses, and notaries. Therefore, it is necessary to harmonize the legislation.

\section{Personal Data Acquired and Collected Indirectly}

Article 15 Paragraph (3) Government Regulation Number 82 Year 2012 About Implementation Of Electronic Systems And Transactions arranges that:

Further provisions regarding the protection of Personal Data in the Electronic System as referred to in paragraph (2) shall be regulated in the Ministerial Regulation. In the Regulation of the Minister of Communications and Technology No. 20 of 2016 on Personal Data Protection in the Electronic System Article 10 Paragraph (2) states that: Personal data acquired and collected indirectly should be verified based on the results of various data sources.

Article 39 Paragraph (1) of the Notarial Deed Law explains that: The faculty must meet the following requirements: at least 18 (eighteen) years of age or married; and to do legal act. The word comes from the word facing which dictionary means side or front side. While the word facing is interpreted as coming to meet with; come see. So it is necessary to harmonize between legislation.

\section{Liabilities Related to the Retention Period of Personal Data}

Article 15 Paragraph (3) of Government Regulation Number 82 Year 2012 Concerning the Implementation of Electronic Transaction and System provides that:

Further provisions concerning Personal Data Protection guidelines in Electronic Systems as referred to in paragraph (2) shall be stipulated in a Ministerial Regulation. In the Regulation of the Minister of Communications and Informatics No. 20 of 2016 on Protection of Personal Data in Electronic Systems Article 15 Paragraph (3) Personal Data as referred to in paragraph (1) shall be kept in the Electronic System: in accordance with the provisions of laws and regulations governing the obligation for the period of storage of Personal Data in each of the Sector Supervisory and Regulatory Agencies; or at least 5 (five) years, if there is no provision of laws and regulations specifically regulating it.

Therefore, legislation is required that specifically regulates the period of storage of personal data for Notary Public.

\section{Liabilities Associated with the Owner of Personal Data who is no Longer a User}

Article 15 Paragraph (3) of Government Regulation Number 82 Year 2012 Concerning the Implementation of Electronic Transaction and System provides that: Further provisions concerning Personal Data Protection guidelines in Electronic Systems as referred to in paragraph (2) shall be stipulated in a Ministerial Regulation. In the Regulation of Minister of Communication and Information 
Technology Number 20 Year 2016 About Protection of Personal Data In Electronic System Article 16 mentioned that: If the Owner of the Personal Data is no longer a User, Electronic System Organizer shall keep such Personal Data within the time limit referred to in Article 15 paragraph (2) from the date of the last Personal Data Owner becomes User.Therefore, it is necessary to harmonize Legislation related to the owner of Personal Data who is no longer a User, for example Notary in question passed away.

\section{The Liability Associated with the Retention of Personal Data Has Exceeded the Time Limit so that Personal Data in Electronic Systems May be Written off}

Article 15 Paragraph (3) of Government Regulation Number 82 Year 2012 Concerning the Implementation of Electronic Transaction and System provides that: Further provisions concerning Personal Data Protection guidelines in Electronic Systems as referred to in paragraph (2) shall be stipulated in a Ministerial Regulation.

In the Regulation of Minister of Communications and Information Technology Number 20 Year 2016 About Protection of Personal Data In Electronic System Article 19 mentioned that:

If the Personal Data retention time has exceeded the time limit referred to in Article 15 paragraph (2), Personal Data in Electronic Systems may be written off unless such Personal Data will still be used or utilized in accordance with the original purpose of acquisition and collection. So, harmonization and clarity of Legislation concerning the time of storage of Personal Data has exceeded the time limit so that Personal Data in Electronic System can be abolished.

\section{Regulations on the Exchange of Personal Data Across Borders}

Article 15 Paragraph (3) of Government Regulation Number 82 Year 2012 Concerning the Implementation of Electronic Transaction and System provides that: Further provisions concerning Personal Data Protection guidelines in Electronic Systems as referred to in paragraph (2) shall be stipulated in a Ministerial Regulation. In the Regulation of Minister of Communication and Information Technology Number 20 Year 2016 About Protection of Personal Data In Electronic System Article 22 mentioned that:

Private Data Delivery managed by Electronic System Provider in governmental institution and local government and public or private domiciled within the territory of the Republic of Indonesia to the territory of the Republic of Indonesia shall apply the provisions of laws and regulations concerning the exchange of Personal Data across borders. Article 18 of the Notary Law states that: Notary has a domicile in the regency or city.

Notary has a position of office covering all provinces from its domicile. UUJN does not regulate the exchange of Cross-border Private Data. Therefore, the authors argue that necessary harmonization between the provisions of the legislation.

\section{The Obligation to Provide Personal Data Contained in Electronic Systems or Personal Data Generated by Electronic System for the Purpose of Law Enforcement Process}

Article 15 Paragraph (3) of Government Regulation Number 82 Year 2012 Concerning the Implementation of Electronic Transaction and System provides that: Further provisions concerning Personal Data Protection guidelines in Electronic Systems as referred to in paragraph (2) shall be 
stipulated in a Ministerial Regulation. In the Regulation of the Minister of Communications and Informatics No. 20 of 2016 on Protection of Personal Data in Electronic Systems Article 23 mentioned that: For the purposes of the law enforcement process, Electronic Systems Organizer is required to provide Personal Data contained in Electronic Systems or Personal Data generated by the Electronic System at the request of law enforcement officers in accordance with the provisions of legislation. Whereas in Article 66 Paragraph (1) of Notary Law, it is mentioned that: For the sake of the judicial process, the investigator, the public prosecutor or the judge with the approval of the Regional Supervisory Council is authorized: taking photocopies of Minuta Deed and/ or letters attached to Minutes of Deed or Notary Protocol in the Notary's depository; and invokes a Notary to be present in the examination relating to the deed he has made or the Notary Protocol which is deposited in the Notary's depository. Therefore, harmonization is required between the provisions of the Law.

\section{Destruction of Personal Data}

Article 15 Paragraph (3) of Government Regulation Number 82 Year 2012 Concerning the Implementation of Electronic Transaction and System provides that: Further provisions concerning Personal Data Protection guidelines in Electronic Systems as referred to in paragraph (2) shall be stipulated in a Ministerial Regulation. In the Regulation of Minister of Communication and Information Technology Number 20 Year 2016 on Protection of Personal Data In Electronic System Article 25 it is mentioned that:

Destruction of Personal Data in Electronic Systems can only be done if: has passed the provisions of the period of storage of Personal Data in Electronic System under this Ministerial Regulation or in accordance with the provisions of other laws and regulations specifically regulating in each of the Supervisory and Sector Regulatory Authorities for that purpose; or at the request of the Owner of Personal Data, unless otherwise provided by the provisions of the law. The Notary Protocol in which to contain Personal Data can not be destroyed and even passed to be maintained by other Notary. Therefore, the authors argue that the necessary harmonization between the provisions of the legislation.

\section{The Obligation to Educate Electronic System Users}

Article 24 of Government Regulation Number 82 Year 2012 Concerning the Implementation of Electronic Transaction and System provides that: (1) The Operator of Electronic System shall be obliged to educate the Electronic System User; (2) Education as referred to in paragraph (1) shall at least concern the rights, obligations and responsibilities of all parties concerned, and procedures for filing a complaint. Whereas in Article 15 Paragraph (2) letter e of the Notary Law shall be stipulated that the Notary is also authorized to provide legal counseling in relation to the making of the deed. Therefore, harmonization is required between the provisions of the Law.

\section{Obligations of Electronic Systems Providers to Provide Facilities for Correcting}

Article 26 of Government Regulation Number 82 Year 2012 Concerning the Implementation of Electronic Transaction and System provides that: The Operator of Electronic System shall provide features in accordance with the characteristics of the Electronic System it uses. The features referred to in paragraph (1) shall be at least in the form of facilities to: make corrections; cancel command; provide confirmation or confirmation; choose to continue or stop carrying out the next activity; view the information submitted in the form of contract offer or advertisement. 
Article 48 of the Notary Law states that: The contents of the deed may not be altered or supplemented, either in the form of composition, insertion, deletion or deletion and replacing it with another. Changes to the deed in the form of additions, replacements or deletions in deeds are only valid if the change is initialed or otherwise marked by other witnesses, witnesses and notaries. Therefore, harmonization is required between the provisions of the Law.

17. The Obligations of the Operator of Electronic Systems Provide Information Contained in the Electronic System or Information Produced by the Electronic System Upon the Legitimate Request of the Investigator for Certain Offenses

Article 29 of Government Regulation Number 82 Year 2012 Concerning the Implementation of Electronic Transaction and System provides that:

For the purposes of the criminal justice process, the Electronic System Operator shall provide information contained in the Electronic System or information produced by the Electronic System at the request of the investigator for certain offenses in accordance with the authorities provided for by law.

Article 66 Paragraph (1) of the Notary Law states that:

For the purposes of the judicial process, the investigator, the public prosecutor, or the judge with the approval of the Regional Supervisory Board is authorized: taking photocopies of Minuta Deed and/ or letters attached to Minutes of Deed or Notary Protocol in the Notary's depository; and invokes Notary to be present in the examination relating to the deed which it has made or the Notary Protocol which is in the Notary's depository.

Harmonization between UU ITU and UUJN is required regarding the mechanism of provision of information contained in the Electronic System for the purposes of the judicial process.

\section{Obligation to Have Certificate of Electronic System Eligibility}

Article 30 of Government Regulation Number 82 Year 2012 Concerning the Implementation of Electronic Transaction System and Transaction stipulates that: The Operator of Electronic System for public service is required to hold Certificate of Electronic System Eligibility. Electronic System Certificate as referred to in paragraph (1) shall be obtained after going through the process of Certification of Electronic System Eligibility. The obligations referred to in paragraph (1) may be applied to all components or parts of Electronic Systems in accordance with the characteristics of protection needs and the strategic nature of the operation of Electronic Systems. The application of the provisions referred to in paragraph (1) and paragraph (2) shall be stipulated by the Minister after coordinating with the head of the relevant Sector and Sector Regulator.

Article 67 of Notary Law states that: Supervision over a Notary is performed by the Minister. In conducting the supervision as referred to in paragraph (1) the Minister shall establish the Supervisory Board. The Supervisory Board as referred to in paragraph (2) shall be 9 (nine) persons, consisting of: government as much as 3 (three) persons; Notary organizations of 3 (three) persons; and experts/ academics as much as 3 (three) people.

Therefore, harmonization is required between the provisions of the Law. 


\section{Provisions Concerning the Procedures for Granting Certification of Electronic Certification Providers Do not Yet Exist}

Article 61 Paragraph (4) of Government Regulation Number 82 Year 2012 Concerning the Implementation of Electronic Transaction and System provides that:

Further provisions concerning the procedure of granting recognition of electronic certification providers are stipulated in a Ministerial Regulation.

The Minister Regulation as intended in Article 62 Paragraph (4) is still missing, but according to the Press Release no. 01 / HM / KOMINFO / 01/2018 dated January 4, 2018 Concerning Public Consultation The draft Ministerial Regulation Regarding the Implementation of Electronic Certification states that the Ministerial Regulation is still in the Public Consultation.

\section{Conclusion}

There are several amendments to legislation which, among other things, must be regulated concerning Registration of Electronic Systems Provider for Public Services for individuals; Minister Regulation as meant in Government Regulation Number 82 Year 2012 concerning Electronic System and Transaction Article 7 Paragraph (2) does not yet exist; Minister Regulation as meant in Government Regulation Number 82 Year 2012 concerning Electronic System and Transaction Article 62 Paragraph (4) does not yet exist; special arrangement is required regarding the role of Notary as a trusted third-party source code store or escrow source code along with inspection mechanisms if necessary for the sake of an investigation; there is a need for arrangements relating to Electronic Systems Organizer Management so that the Notary can guarantee the availability of service level agreements, the availability of information security agreements on the Information Technology services used and the security of internal communications and information held; a strict regulation of the Supervisory and Sector Overseers is required as a determinant of relevant information criteria in relation to data collection; necessary harmonization of legislation relating to the Protection of Personal Data in Electronic Systems; necessary harmonization of legislation related to the obligation to educate to Electronic System Users; necessary harmonization of legislation relating to the obligation to perform providing features in accordance with the characteristics of Electronic Systems used; necessary harmonization of legislation related to the obligation to provide, educate, and train personnel in charge and responsible for securing and protecting facilities and infrastructure of Electronic System; necessary harmonization of legislation relating to the obligation to provide information contained in the Electronic System or information generated by the Electronic System for the benefit of the court; required harmonization of legislation related to the relevant Sector and Sector Regulator.

\section{References}

Satjipto Rahardjo. (2009). Hukum dan Perilaku: hidup baik adalah dasar hukum yang baik, Kompas, Jakarta.

Assafa Endeshaw. (2007). Hukum E-Commerce dan Internet Dengan Fokus Di Asia Pasifik, Yogyakarta: Pustaka Pelajar.

Achmad Ali. (2011). Menguak Tabir Hukum, Ghalia Indonesia, Bogor. 
Mahmutarom. (2006). Pembangunan Hukum Nasional dalam Konteks Global, dalam Menggagas Hukum Progresif Indonesia, Pustaka Pelajar, Yogyakarta.

Satjipto Rahardjo. (2008). Merencanakan Pembangunan Hukum Dalam Era Demokrasi, Transparasi dan Perkembangan Sains, Seminar dan Temu Hukum Nasional IX di Yogyakarta 20-21.

Arsyad Sanusi. (2005). Hukum Dan Teknologi Informasi, M. Arsyad Sanusi, Jakarta.

Sukarmi. (2008). Cyber Law: Kontrak Elektronik dalam Bayang-Bayang Pelaku Usaha (Cyberlaw Indonesia), Pustaka Sutra, Bandung.

Edmond Makarim. (2013). Notaris dan Transaksi Elektronik: Kajian Hukum Tentang Cybernotary atau Electronic Notary, Depok, Rajagrafindo Persada.

Law Number 8 of 1997 concerning Company Documents.

Law Number 30 Year 2004 About Position of Notary.

Law Number 11 Year 2008 regarding Information and Electronic Transactions.

Law Number 2 Year 2014 On Amendment to Law Number 30 Year 2004 About Position of Notary.

Law Number 19 Year 2016 About Amendment to Law Number 11 Year 2008 About Information and Electronic Transactions.

\section{Copyrights}

Copyright for this article is retained by the author(s), with first publication rights granted to the journal.

This is an open-access article distributed under the terms and conditions of the Creative Commons Attribution license (http://creativecommons.org/licenses/by/4.0/). 